heos an. J. Alonso Diaz z Uniwersytetu Comillas mówił nt. Upadek błędnie pojmowanego oczekiwania królestwa Bożego 'i jego przekształcenie po zmartwychwstaniu Chrystusa. Istota królestwa Bożego głoszonego przez Jezusa zajął się J. C a ballero Cuesta $z$ fakultetu Teol. w Burgos, a A. Rodriguez Carmona z Fakultetu Teol. w Granadzie przedstawił relację królestwa Bożego do eschatologii w nauczaniu Jezusa. Nastẹpne referaty dotyczyły nauki o królestwie Bożym w poszczególnych księgach NT: A. del A gua Perez z Valladolid: Wypełnienie zapowiedzi o królestwie Bożym $w$ programie nauki Ewangelii Eukasza (4, 14-44), Aguirre MI on asterio z Uniw. W Deusto-Bilbao: Królestwo Boże a śmierć Chrystusa $w$ Ewangelii Mateuszowej, Palas Ferragut O.S.A. dyrektor Escuela Biblica en Madrid: Teologia królestwa Bożego w myśli Pawłowej, $\mathrm{R}$. Vincent $\mathrm{S}$ a e ra $\mathrm{z}$ centrum teol. salezjańskiego $\mathrm{w}$ Barcelonie: Zbawcze zadanie niewierności Izraela $w$ liście do $R z$ 9-11, M. Nicolau P ons ze Studium Teologicznego św. Idelfonsa w Toledo przedstawił naukę Listu do Hebrajczyków o królestwie Bożym, omawiając kolejno takie wyrażenia tego listu jak ,królestwo niewzruszone", na czele którego stoi kapłan król (7, $1 \mathrm{nn})$, a następnie które jest miastem, do którego wszyscy wierni pielgrzymuja, aby doznać w nim odpoczynku $(13,14)$.

Ostatnim referatem była prelekcja D. Gonzalo IM a es o: Królestwo Boże w liturgii synagogalnej $i$ chrześcijańskiej stanowiaca znakomite podsumowaÆịe referatów o królestwie Bożym w świetle ksiąg ST, apokryfów i NT.

Pod adresem dyrektora Sekcji Biblijnej Prof. S. Muñoza Iglesiasa należy się serdeczne podziękowanie za pierwsze nawiązanie kontaktów z polską biblistyką, które na pewno rozszerzą się w najbliższej przyszłości.

Dąbrowa Tarnowska

KS. JOZEF $€ A C H$

Ks. Józef Lach

\title{
PIELGRZYMKA KSIĘŻY TARNOWSKICH DO ZIEMI ŚWIĘTEJ
}

Pielgrzymki są objawem religijnej duszy ludzkiej i należą do zjawisk występujących w każdej religii. Zna pielgrzymki również religia objawiona zarówno w Starym i Nowym Przymierzu. Pielgrzymował lud Boży do świątyni w Jerozolimie nie tylko od najdalszych granic swego państwa od Dan po Bereszebę, ale i ci, którzy żyli w diasporze na dalekim Zachodzie i Wschodzie, Północy czy Południu, śpiewając po drodze specjalne Psalmy pielgrzymów, czy też specjalne hymny na cześć stolicy prawdziwego Boga, wielkiego króla w Jerozolimie. Pielgrzymowali też do Ziemi świętej chrześcijanie poprzez dwadzieścia wieków swego istnienia. Szli święci i pokutnicy nieraz z wielkim ryzykiem nie tylko dla swego zdrowia, ale nawet i życia.

Szczególnie w czasach współczesnych przy ułatwieniach komunikacyjnych Ziemia święta ściąga miliony pielgrzymów z całego świata. Przede wszystkim do Ziemi świętej pielgrzymują kapłani, gdyż wciąż o tej Ziemi świętej rozmyślają i mówią ludowi. Nic dziwnego, że polscy kapłani zaczynają w ostatnich czasach coraz częściej pielgrzymować do Ziemi świętej pojedynczo, czy dołączając się do różnych zagranicznych pellegrinaggi. $Z$ radościa należy podkreślić, że wśród tych różnych pellegrinaggi duchownych do Ziemi świętej środowisko tarnowskie, obejmujace głównie profe- 
sorów Tarnowskiego Seminarium duchownego pod przewodnictwem wykładowcy Pisma św. NT. Ks. dr M. Bednarza, zorganizowało pierwszą po II wojnie światowej diecezjalną pielgrzymkę księży w liczbie 46. Pielgrzymi jedną część drogi odbyli pociągami (Tarnów-Budapeszt,-Bukareszt, względnie Tarnów-Lwów-Bukareszt), a druga część drogi samolotem linii rumuńskich Bukareszt-Tel-Aviv. Wyjazd z Tarnowa nastąpił 15 i 16 lipca 1978, a odlot z Bukaresztu do Tel-Avivu 18 lipca rano i przylot wszystkich przed południem tego samego dnia do Tel-Aviv, a stąd samochodami do Jerozolimy, gdzie rozlokowali się w dwóch polskich domach, którymi opiekują się polskie SS. Elżbietanki.

Dwa cele postawili sobie organizatorzy i uczestnicy tej pielgrzymki: religijny i naukowy. Celowi religijnemu służyły koncelebry ze Słowem Bożym przekazującym różne zdarzenia $\mathrm{z}$ historii zbawienia. Homilie objaśniające te zdarzenia biblijne wygłaszali poszczególnie kapłani. Te koncelebry i homilie wygłaszane $\mathrm{z}$ namaszczeniem były niezapomnianym przeżyciem dla wszystkich pielgrzymów. Po koncelebrze następował zwyczajnie kompetentny wykład naukowy ks. Bednarza, który po zakończeniu studiów biblijnych na Pap. Instytucie Biblijnym $w$. Rzymie $z$ polecenia Ordynariusza Tarnowskiego JE Bpa J. Ablewicza przez dwa lata studiował archeologię w Ecole Biblique et Archéologique Française de Jérusalem.

Zasadniczo pielgrzymka trwała dwa tygodnie tj. do 1 . VIII. $78 \mathrm{r}$. ale dla tych, którzy chcieli pozostać dłużej, aby prywatnie pomodlić się w sanktuariach jerozolimskich, czy aby rozglądnąć po bibliotekach czy muzeach biblijnych w Jerozolimie, istniała możliwość pozostania jeszcze $5-9$ dni, tj. do 9. VIII. br.

Poza jedną nocą z 25 na 26 lipca, gdzie pielgrzymi nocowali w Eilat (Aqaba) nad morzem Czerwonym, 20.000 tysięcznym porcie, zawsze na noc przybywali do Jerozolimy. Stąd autokarami, względnie pieszo - jeśli chodziło o bliższe sanktuaria - udawali się niemal codziennie na modlitwe i zwiedzanie różnych miejsc świętych, w szczególniejszy sposób związanych $\mathrm{z}$ historią zbawienia. Trudno tu je wszystkie wyliczyć. Dość wspomnieć, że przemierzyliśmy dzięki znakomitym środkom komunikacyjnym wszerz i wzdłuż Ziemię św.

Na południu przebywając w Eilat byliśmy niedaleko góry dekalogu Dżebel Musa, (Synaj) zatrzymując się u stóp wzgórz Golan byliśmy znów blisko miast fenickich: Tyru, Sydonu i Damaszku. Szkoda, że bariery graniczne i bratobójcze walki w Bejrucie nie pozwoliły nam zwiedzić gór Libanu i Antylibanu i innych miejsc związanych z tradycją zawartą w Biblii.

Najwięcej czasu poświęciliśmy Jerozolimie, potem Galilei, a wreszcie Samarii. Już w pierwszym dniu po chwilowym wypoczynku w Domach polskich udaliśmy się wspólnie na zwiedzenie miejsca śmierci, grobu i Zmartwychwstania Pana Jezusa. Tu zdaliśmy sobie sprawę, że znajdujemy się w najważniejszym miejscu na ziemi dla każdego chrześcijanina. Tu też cały czas naszego pobytu w Ziemi św. biegły nasze oczy, tu przychodziliśmy razem i osobno, aby wielbić, dziękować za łaskę Odkupienia, za Zmartwychwstanie Jezusa, które jest główną podstawą naszego Zmartwychwstania.

Po koncelebrze i wykładzie o bązylice Grobu Pańskiego na drugłi dzień 19. VII. udaliśmy się do pięknego Nazaretu, gdzie Pan Jezus spędził okolo 30 lat życia i gdzie dokonało się Wcielenie dzięki potężnemu słowu Maryi: Fiat. Tutaj serca polskich kapłanów szczególniej czuły się dobrze, jakby w gościnie u Swej Matki. Stąd tego samego dnia odwiedziliśmy pobliską Kanę, gdzie Jezus uczynił pierwszy cud na prośbę Swej Matki, polecając Tej Matce wszystkie nasze potrzeby - Kościoła, Diecezji i Ojczyzny.

Również w następnym dniu (20. VII.) udaliśmy się do pięknej Galilei zatrzymując się na Górze Przemienienia (tj. Tabor), a później w Betsaidzie 
(Tabghe) w Kafarnaum, gdzie Pan Jezus zapowiedział ustanowienie Eucharystii (zob. J 6).

Jeszcze w dwa dni później poświęciliśmy jeden dzień na pielgrzymkę do Galilei, na górę Błogosławieństw, gdzie Chrystus w Kazaniu na górze ogłosił Konstytucję swego królestwa, a stąd udaliśmy się na północ do źródeł Jordanu aż do Cezarei Filipowej, gdzie znów Chrystus uczynił Szymona z Betsajdy Skałą (Piotrem) niezwyciężonego Królestwa. A więc trzy dni trwało w sumie pielgrzymowanie po Galilei, krainie Jezusa i niektórych Apostołów.

Jeden dzień (23. VII.) poświęcono Samarii, Sebaste, stolicy królestwa północnego, gdzie Pan Jezus przy studni Jakubowej w Sychar (Szechem Nablus) objawił się jako oczekiwany Mesjasz i gdzie zapowiedział, że nadchodzi godzina, kiedy Jego Ojciec będzie odbierał cześć nie tylko w Jerozolimie i Samarii, ale na każdym miejscu (por. J 4, 1-43).

Wtedy też zwiedziliśmy góry Garizim i Ebal, gdzie po wejściu ludu Bożego do Ziemi Obiecanej nastąpiło z nakazu Mojżesza oc̉nowienie przymierza synajskiego (Pwt 27, 1-6; por. Joz 8, 30-3). Po drodze do Jerozolimy zwiedzono jeszcze Megiddo, równinę Ezdrelon, przez które w ciagu wieków przeciągały różne armie egipskie, asyryjskie czy greckie na podbój Egiptu czy Mezopotamii. Tego dnia zwiedzono również górę Karmel, słynną zwłaszcza z opowiadań biblijnych o Eliaszu (2 Krl 18), Haifę oraz Cezareę wspomnianą w Dziejach Apostolskich.

Najwięcej czasu poświęcono zwiedzaniu samej Jerozolimy, liczącej według spisu ze stycznia 1978 r. 371.000 mieszkańców, miasta Dawida, Salomona i stolicy królestwa południowego aż po ostatniego króla Sedecjusza, miasta proroków: Izajasza, Micheasza, Jeremiasza, Habakuła, Sofoniasza, Ezechiela, Aggeusza i Zachariasza, miasta gdzie Pan Jezus został na śmierć skazany, gdzie odbył bolesną Drogę Krzyżową, gdzie się znajduje góra Oliwna, skąd wjechał triumfalnie do Jeroozlimy i skąd po śmierci wstąpił do Ojca, gdzie mieści się Wieczernik, gdzie ustanowił Najświętszy Sakrament, oraz gdzie nastąpiło zesłanie Ducha św. czy w końcu Jerozolimę, gdzie na Syjonie miała zasnąć Najświętsza Maryja Panna, Matka Syjonu-Kościoła. Tym wszystkim miejscom świętym w Jerozolimie poświęcono najwięcej wspólnych modlitw i rozważań bo aż 6 dni $(18,21,24,27$, 28, 29 lipca).

Oprócz Jerozolimy odwiedziliśmy mieszczące się w Judei dwie miejscowości drogie sercu pielgrzyma, jedno to Ain Karim, odległe od Jerozolimy o $7 \mathrm{~km}$, ojczyznę Jana Chrzcicielá, gdzie nastąpiło pierwsze pozdrowienie religijne Maryi, jako Matki Bożej przez św. Elżbietę: Skądże to, $\dot{z} e$ przychodzi do mnie Matka Pana mego? i gdzie po raz pierwszy Maryja: wyśpiewała hymn Magnificat (Łk 1, 45nn).

Zwiedzanie kościoła, gdzie miało nastąpić powitanie Maryi i Jej odpowiedź odtworzona w licznych językach (także i w polskim) na zewnętrznej ścianie kościoła, zwanego kościołem Nawiedzenia, a także poznanie kościoła, gdzie miał się narodzić Jan Chrzciciel, zwanego tradycyjnie domem Jana, było miłym uzupełnieniem wrażeń przeżytych w pobliskiej Jerozolimie.

Ale chyba po Nazarecie, po Jerozolimie szczególnie niezapomniane wrażenie wywarła na każdym pielgrzymie podróż do Betlejem, gdzie narodzif się poczęty za sprawą Ducha Sw. w Nazarecie Jezus Chrystus, w starym mieście przynależnym do dynastii Dawida. Srebrna gwiazda znajdująca się w grocie pod bazylika Narodzenia posiada napis: „Tutaj z Dziewicy Maryi narodził się Jezus Chrystus". Na próżno usiłował cesarz Hadrian zatrzeć pamięć o tym miejscu świętym przez wzniesienie tutaj, jak i na grobie Jezusa, świątyń pogańskich. Zwycięstwo Konstantyna przywróciło kultowi chrześcijan oba te sanktuaria, jak i inne miejsca w Ziemi świętej.

To obcowanie wspólne przez dwa tygodnie z tymi różnymi sanktuariami związanymi z Pismem św. odświeżyło u uczestników znajomość Biblii, 
a także pobyt czy to w Qumran, Masadzie czy to muzeach różnego typu ukazało z jednej strony świadków dowodzących powagi tekstów biblijnych, a z drugiej strony ukazało nam kulturę materialną ludzi występujących na kartach obu Testamentów. Dla tych, którzy, jak piszący, mogli sobie przedłużyć o 8 dni pobyt w Ziemi świętej, stanowiło to solidną podstawę do prywatnego odwiedzenia zarówno sanktuariów jerozolimskich, jak i muzeów oraz instytutów naukowych, aby przez to posiąść lepszą znajomość Pisma św. które od Boga natchnione (jest) $i$ pożyteczne do nauczenia, do przekonywania, do poprawienia, do kształcenia w sprawiedliwości, aby człowiek Boży był doskonaty przysposobiony do każego dobrego czynu (2 $\operatorname{Tm} 3,16-17)$.

Dabrowa Tarnowska

KS. JOZEF EACH

\section{O. AUGUSTYN JANKOWSKI CZEONKIEM PAPIESIKIEJ KOMISJI BIBLIJNEJ}

Biletem Sekretariatu Stanu z dnia 11 lipea $1978 \mathrm{r}$. Papież Paweł VI mianował o. prof. dr hab. Augustyna JANKOWSKIEGO, OSB, członkiem Papieskiej Komisji Biblijnej. Ojcu Profesorowi, długoletniemu współpracownikowi naszego czasopisma, Redakcja składa serdeczne gratulacje.

A oto pozostali mianowani czlonkowie Papieskiej Komisji Biblijnej: J. Quinn (USA), M. Vellanickal (Indie), L. Nare' (Górna Wolta), J. Greehy (Irlandia), G. Couturier CSC (Kanada), A. Penna CRL (Włochy). 